\title{
Michat Zaremba* \\ INTEGRACJA MONETARNA W AFRYCE ZACHODNIEJ - ROZWÓJ I FUNKCJONOWANIE STREFY FRANKA CFA
}

\begin{abstract}
Streszczenie. Niniejszy artykuł ma na celu zaprezentowanie rozwoju i historii funkcjonowania afrykańskiej strefy franka CFA, będącego oficjalną walutą w dwóch afrykańskich ugrupowaniach integracyjnych - Zachodnioafrykańskiej Unii Gospodarczej i Walutowej oraz Wspólnocie Ekonomicznej i Monetarnej Afryki Centralnej. W pierwszej części pracy skupiono się na teoretycznych aspektach integracji walutowej, natomiast drugą poświęcono analizie procesów integracji walutowej na tym kontynencie.
\end{abstract}

Słowa kluczowe: integracja ekonomiczna, Afryka, unia walutowa.

\section{WPROWADZENIE}

Proces integracji walutowej, czyli zastępowania waluty narodowej jedną walutą, wspólną dla krajów będących w danej unii monetarnej jest jednym z najbardziej interesujących procesów postępujących w gospodarce globalnej. Procesy te, zachodzące w wielu rejonach świata, mają również miejsce w Afryce, gdzie z jednej strony są one dziedzictwem czasów kolonialnych, a z drugiej - służą jako narzędzie do osiągnięcia stabilności ekonomicznej i finansowej, która stanowi podstawę osiągania zadowalających wyników gospodarczych.

Niniejszy artykuł ma na celu zaprezentowanie rozwoju i historii funkcjonowania afrykańskiej strefy franka CFA, będącego oficjalną walutą w dwóch afrykańskich ugrupowaniach integracyjnych - Zachodnioafrykańskiej Unii Gospodarczej i Walutowej oraz Wspólnocie Ekonomicznej i Monetarnej Afryki Centralnej. W pierwszej części pracy skupiono się na teoretycznych aspektach integracji walutowej, natomiast drugą poświęcono analizie procesów i skutków integracji walutowej na obszarze strefy franka CFA.

* Uniwersytet Łódzki, Wydział Ekonomiczno-Socjologiczny, Instytut Ekonomii. 


\section{WYBRANE ASPEKTY TEORETYCZNE INTEGRACJI MONETARNEJ}

Integracja gospodarcza jest jednym z najczęściej analizowanych zjawisk zachodzących we współczesnej gospodarce światowej. Proces ten jest wielowymiarowy i złożony, obejmujący całość funkcjonowania gospodarki narodowej i może być rozpatrywany w aspekcie dynamicznym lub statycznym. W sensie dynamicznym jest to proces szerokich dostosowań i przeobrażeń zachodzących w strukturach wewnętrznych gospodarek krajów integrujących się oraz w obszarze wzajemnych relacji, które scalają poszczególne struktury krajowe i tworzą nowe, silne więzy między nimi. W efekcie tworzy się jednolita, spójna i wewnętrznie komplementarna struktura gospodarcza (Makać 2001: 9). W drugim znaczeniu jest to stan braku występowania jakichkolwiek form dyskryminacji między poszczególnymi państwami (Balassa 1961: 1). Integrację gospodarczą można rozpatrywać również jako proces formowania się nowego, opartego na wykształconej, jednolitej strukturze gospodarczej tworu ekonomicznego, który ze względu na wielość, głębokość i spoistość wzajemnych powiązań ekonomicznych staje się wyodrębnionym elementem w gospodarce światowej (Kamecki 1967: 93-94).

Skutki procesu integracji ekonomicznej dla gospodarki państwa przystępującego do danego ugrupowania integracyjnego są wielorakie, o charakterze zarówno pozytywnym, jak i negatywnym. Do zalet integracji zalicza się przede wszystkim (por. m.in. Budnikowski 2006: 260; Begg, Fischer, Dornbusch 2003: 440; Rising... 2005: 5; The LIME... 2008: 1):

- korzyści skali - integracja skłania przedsiębiorstwa do koncentracji i produkcji na coraz większą skalę (ze względu na rozszerzony rynek), a w konsekwencji obniżania kosztów jednostkowych;

- lepszą alokację zasobów - poprzez likwidację barier handlowych czynniki wytwórcze są przenoszone i wykorzystywane tam, gdzie osiągają najwyższe stopy zwrotu. W efekcie wzrasta specjalizacja wewnątrz- i międzygałęziowa;

- wzrost efektywności poprzez nasilenie się konkurencji - import dóbr substytucyjnych zmusza krajowych producentów do bardziej konkurencyjnych zachowań, m.in. do obniżenia cen towarów i usług oraz zwiększenia aktywności gospodarczej w zakresie innowacyjności oraz produktywności;

- transfer wiedzy i technologii - poprzez napływ bezpośrednich inwestycji zagranicznych przekazywana jest technologia oraz wiedza menedżerska krajom goszczącym, pomimo braku uczestnictwa kompetencyjnego czy finansowego w pracach nad ich powstaniem;

- pełniejsze wyeksploatowanie korzyści komparatywnych - zgodnie z klasyczną teorią dopóki kraje będą wykazywać różnice w zakresie specjalizacji branżowej lub wydobycia surowców, będą także uzyskiwać korzyści z handlu, a usunięcie barier handlowych może tylko przyczynić się do pełniejszego wyeksploatowania korzyści komparatywnych; 
- zwiększenie poziomu inwestycji - napływający kapitał zagraniczny pozwala na poziom inwestycji przekraczający krajowe oszczędności;

- zmuszenie rządów do prowadzenia poprawniejszej polityki makroekonomicznej i wydawania lepszych regulacji krajowych ze względu na zagrożenie możliwością odpływu obcego kapitału oraz kontrolę sprawowaną przez niezależne instytucje wspólnotowe;

- poprawę perspektyw wzrostu gospodarczego i zatrudnienia - inwestycje za granicą i import zmuszają gospodarkę do utrzymywania odpowiedniego poziomu konkurencyjności, co pozytywnie wpływa na krajowe zatrudnienie. Z kolei inwestycje w kraju i eksport zwiększają wzrost gospodarczy i kreują miejsca pracy.

Negatywne aspekty integracji ekonomicznej koncentrują się natomiast wokół następujących kwestii (por. m.in. Molle 1992: 10-34; Stehn 1992: 108-112):

- możliwego osłabienia gospodarki krajowej wskutek odpływu kapitału, który mógłby służyć finansowaniu inwestycji i bieżącej działalności podmiotów krajowych;

- ubytku rezerw walutowych jako skutku szerokiego otwarcia gospodarki na towary i usługi z krajów bardziej konkurencyjnych;

- możliwego negatywnego wpływu na równowagę wewnętrzną i zewnętrzną kraju;

- możliwości „,importu” inflacji;

- wolny przepływ kapitału prowadzić może do jego koncentracji w krajach o dużych rynkach, z obfitą podażą kapitału, prowadząc do wzrostu zróżnicowania w rozwoju przez asymetryczną alokację;

- ograniczonej skuteczności krajowej polityki makroekonomicznej, ze względu na przekazanie części uprawnień w prowadzeniu polityki gospodarczej na rzecz instytucji ponadnarodowych ugrupowania integracyjnego;

- możliwego wzrostu bezrobocia i redukcji płac w gospodarce krajowej wskutek importu towarów i usług z krajów o kosztowej przewadze konkurencyjnej.

$\mathrm{Z}$ procesami integracji ekonomicznej jest ściśle powiązany proces integracji monetarnej (walutowej). Sam proces integracji monetarnej może być różnie definiowany, przy czym brak jest konsensusu co do większości wypracowanych definicji (por. m.in. Bilski 2006: 151-154; Gandolfo 1992: 765). Może być ona uznana za element szerszej integracji gospodarczej, której istotą jest integracja, przenikanie się oraz wzrost współzależności poszczególnych branż i sektorów gospodarek unifikujących się, prowadzący do powstania rozległych obszarów gospodarczych (Machlup 1986: 18). Może być również definiowana jako integracja rynków kapitałowych, wyrażająca się pełną swobodą w przepływach kapitału oraz unią kursową realizowaną poprzez pełną wymienialność walut państw członkowskich lub też wprowadzeniem jednej, wspólnej waluty dla całego ugrupowania integracyjnego (Bożyk, Misala 2003: 159-161). Inni badacze rozpatrują to zjawisko jako proces prowadzący do osiągnięcia pełnej wymienialności walut oraz, finalnie, wprowadzenia jednej, wspólnej waluty w miejsce walut narodowych 
w państwach integrujących się. Tak rozumiana integracja oznacza również rezygnację z części prerogatyw ekonomicznych na rzecz ponadnarodowych instytucji danego ugrupowania integracyjnego (por. m.in. Coffey, Presley 1976: 24).

Jedną $z$ najciekawszych $i$, jak się wydaje, najczęściej analizowanych teorii związanych z powstaniem i rozwojem procesu integracji ekonomicznej jest sformułowana przez R. Mundella w $1961 \mathrm{r}$. teoria optymalnego obszaru walutowego (Mundell 1961: 657-665). Choć pojęcia integracji monetarnej i optymalnego obszaru walutowego nie są tożsame, to ze względu na wspólne cechy w literaturze niejednokrotnie przyjmuje się przesłanki teoretyczne tworzenia optymalnego obszaru walutowego także w odniesieniu do procesu integracji monetarnej i tworzenia unii monetarnych (por. Wojtyna 1998: 8-15). Zgodnie z teorią Mundella przez optymalny obszar walutowy rozumie się taki obszar, na którym (Mundell 1968: 144):

- funkcjonują waluty narodowe, połączone sztywnymi i nieodwołalnymi kursami walutowymi lub też funkcjonuje jedna wspólna waluta, która zastąpiła waluty krajowe;

- doszło do unifikacji polityki monetarnej, która jest koordynowana przez jedną, ponadnarodową instytucję;

- efektowność polityk makroekonomicznych jest wysoka, gwarantująca osiągnięcie ogólnej stabilności gospodarczej (stabilność cen, niski poziom bezrobocia, równowaga zewnętrzna).

Wykorzystane przez Mundella określenie „optymalny” oznacza taki stan, przy którym dana gospodarka jest $\mathrm{w}$ stanie utrzymać pożądany stan równowagi zewnętrznej i wewnętrznej. Z kolei określenie „obszar”, w rozumieniu autora teorii, nie wiąże się z kryterium geograficznym, a oznacza po prostu grupę krajów podobnych pod względem struktury produkcji i w podobnym stopniu podatnych na zmiany w gospodarce. Implikuje to, że najlepszymi kandydatami są państwa, których gospodarki są podobne do siebie pod względem strukturalnym.

Kolejni ekonomiści wzbogacali teorię optymalnych obszarów walutowych. W artykule Optimum currency areas R. I. McKinnon (1963: 717-725) zaproponował uznanie mobilności czynników produkcji za kolejny warunek sprawnego funkcjonowania wspólnego obszaru walutowego. Zgodnie z jego sugestiami mobilność czynników produkcji stanowi mechanizm reagujący na zmiany popytu i podaży, a elastyczność cen i płac wspomaga absorpcję szoków asymetrycznych.

Z kolei P. B. Kenen (1969: 41-60) uważał, że optymalny obszar walutowy może być tworzony przez kraje, których produkcja i eksport są zdywersyfikowane, a gospodarki charakteryzują się podobną strukturą. Zróżnicowanie produkcji i eksportu zmniejsza ryzyko szoku asymetrycznego, gdyż tempo spadku popytu jest inne w zależności od sektorów gospodarki i grup towarowych.

Ze względu na zmiany w gospodarce światowej i upadek systemu z Bretton Woods w latach 70. XX w. autor koncepcji optymalnych obszarów walutowych, R. Mundell zaczął traktować taki obszar przede wszystkim jako sposób na ograniczenie manipulacji kursami walutowymi oraz przesłankę do stworzenia funduszu 
rezerw walutowych, który stanowiłby skuteczny instrument stabilizacji gospodarczej, służący absorpcji asymetrycznych szoków zewnętrznych (Verde 2009: 113).

Milowym krokiem i przełomem w badaniach nad optymalnymi obszarami walutowymi były prace J. Frankela i A. Rose'a, którzy przedstawili w roku 1998 tezy o endogeniczności kryteriów optymalnego obszaru walutowego (Frankel, Rose 1998: 1009-1025). Sformułowali oni tezy, zgodnie z którymi ustanowienie jednego obszaru ze wspólną walutą samo w sobie przyczynia się do intensyfikacji wymiany handlowej. Wzrastające powiązania między krajami z kolei przyczyniają się do synchronizacji faz cyklu koniunkturalnego. W efekcie tych procesów oraz szybszej konwergencji kryteria optymalnego obszaru walutowego mogą być spełnione ex post. Oznacza to, że kraje nie muszą być ze sobą istotnie powiązane ekonomicznie, by tworzyć wspólny obszar walutowy, bowiem samo jego ustanowienie przyczynia się do konwergencji gospodarczej.

Mimo niewątpliwej zalety teorii optymalnych obszarów walutowych, jaką jest stworzenie metodologicznego podejścia do idei integracji i unii monetarnych, teoria ta cechuje się jednak licznymi wadami, do których zalicza się przede wszystkim tzw. problem endogeniczności warunków optymalności: nie jest wiadome, czy powołanie do życia danego obszaru jest zasadne, gdy warunki są zrealizowane, czy też sam fakt ustanowienia unii prowadzi do spełnienia tychże warunków (Wyplosz 2006: 207-261). Ponadto dowodzi się, że procesy intensyfikacji handlowej prowadzą nie tyle do rozwoju dywersyfikacji produkcji, ile do rozwoju specjalizacji. Im mniejsza dywersyfikacja krajów obszaru, tym bardziej są one narażone na szoki asymetryczne (por. m.in. Krugman 1993: 241-266; Tchorek 2010: 60-63).

Za dyskusyjne należy również uznać tezy o pełnej mobilność siły roboczej, co wynika zarówno z przesłanek ekonomiczno-prawnych, jak i społeczno-kulturowych. Założenie o mobilności kapitału jest łatwiejsze do zrealizowania w praktyce społeczno-gospodarczej, niemniej należy dokonać rozróżnienia między mobilnością kapitału portfelowego, który niejako ze swej natury jest bardzo mobilny i inwestycjami bezpośrednimi, których mobilność jest zdeterminowana przez wiele czynników, a ich ewentualna relokacja może być problematyczna. Warunek związany z elastycznością płac jest równie istotny, co trudny do spełnienia. Ewentualna obniżka wynagrodzeń, sprzyjająca wzrostowi konkurencyjności gospodarki może mieć miejsce wyłącznie w sytuacji wyłącznego kształtowania się płac przez grę popytu i podaży na rynku pracy oraz brak wpływu instytucji, takich jak związki pracowników na ten rynek.

Koncepcja optymalnych obszarów walutowych jest stosowana jako ramy teoretyczne dla procesów integracji monetarnej, a nie jako ostateczne i jedyne rozwiązanie. Wynika to przede wszystkim z faktu, że teoria ta nie czyni rozróżnienia pomiędzy systemem stałych kursów walutowych a wspólną walutą oraz niejasnością co do warunków związanych z koordynacją polityki ekonomicznej państw uczestniczących w obszarze jednowalutowym (poza zunifikowaną polityką monetarną), będącą istotnym warunkiem efektywnego funkcjonowania takiego obszaru. 


\section{FUNKCJONOWANIE AFRYKAŃSKIEJ STREFY FRANKA CFA - ZACHODNIOAFRYKAŃSKA UNIA GOSPODARCZA I WALUTOWA ORAZ WSPÓLNOTA EKONOMICZNA I MONETARNA AFRYKI CENTRALNEJ}

Integracja ekonomiczna, w tym monetarna, jest procesem zachodzącym w wielu rejonach świata, stanowiącym, jak się wydaje, jeden z najważniejszych procesów we współczesnej gospodarce światowej (tab. 1).

Tabela 1

Funkcjonujące unie monetarne na świecie

\begin{tabular}{|c|c|c|c|c|}
\hline $\begin{array}{c}\text { Nazwa } \\
\text { unii monetarnej }\end{array}$ & Państwa uczestniczące & $\begin{array}{c}\text { Rok } \\
\text { powstania }\end{array}$ & $\begin{array}{l}\text { Nazwa } \\
\text { waluty }\end{array}$ & $\begin{array}{c}\text { Instytucja pełniąca rolę } \\
\text { banku centralnego }\end{array}$ \\
\hline Strefa euro & $\begin{array}{l}\text { Austria, Belgia, Cypr, } \\
\text { Estonia, Finlandia, Fran- } \\
\text { cja, Grecja, Hiszpania, } \\
\text { Holandia, Irlandia, Luk- } \\
\text { semburg, Łotwa, Malta, } \\
\text { Niemcy, Portugalia, Sło- } \\
\text { wacja, Słowenia, Włochy }\end{array}$ & 1999 & euro & $\begin{array}{l}\text { Europejski Bank Cen- } \\
\text { tralny (European Cen- } \\
\text { tral Bank) }\end{array}$ \\
\hline $\begin{array}{l}\text { Wschodnioka- } \\
\text { raibska Unia } \\
\text { Walutowa }\end{array}$ & $\begin{array}{l}\text { Anguilla, Antigua i Bar- } \\
\text { buda, Dominika, Grena- } \\
\text { da, Saint Kitts i Nevis, } \\
\text { Saint Lucia, Montserrat, } \\
\text { Saint Vincent i Grena- } \\
\text { dyny }\end{array}$ & 1965 & $\begin{array}{l}\text { dolar } \\
\text { wschod- } \\
\text { niokara- } \\
\text { ibski }\end{array}$ & $\begin{array}{l}\text { Wschodniokaraib- } \\
\text { ski Bank Centralny } \\
\text { (Eastern Caribbean } \\
\text { Central Bank) }\end{array}$ \\
\hline $\begin{array}{l}\text { Zachodnioafry- } \\
\text { kańska } \\
\text { Unia Gospodar- } \\
\text { cza i Walutowa }\end{array}$ & $\begin{array}{l}\text { Benin, Burkina Faso, } \\
\text { Gwinea-Bissau, Mali, Ni- } \\
\text { ger, Senegal, Togo, Wy- } \\
\text { brzeże Kości Słoniowej }\end{array}$ & 1994 & $\begin{array}{l}\text { frank } \\
\text { CFA }\end{array}$ & $\begin{array}{l}\text { Bank Centralny Kra- } \\
\text { jów Afryki Zachodniej } \\
\text { (Banque Centrale des } \\
\text { États de l'Afrique de } \\
\text { l'Ouest) }\end{array}$ \\
\hline $\begin{array}{l}\text { Wspólnota Eko- } \\
\text { nomiczna } \\
\text { i Monetarna } \\
\text { Afryki Cen- } \\
\text { tralnej }\end{array}$ & $\begin{array}{l}\text { Czad, Demokratyczna } \\
\text { Republika Konga, Gabon, } \\
\text { Gwinea Równikowa, } \\
\text { Kamerun, Republika } \\
\text { Środkowoafrykańska }\end{array}$ & 1994 & $\begin{array}{l}\text { frank } \\
\text { CFA }\end{array}$ & $\begin{array}{l}\text { Bank Krajów Afryki } \\
\text { Centralnej (Banque des } \\
\text { États de l'Afrique Cen- } \\
\text { trale) }\end{array}$ \\
\hline $\begin{array}{l}\text { Strefa randa } \\
\text { południowoa- } \\
\text { frykańskiego }\end{array}$ & $\begin{array}{l}\text { Lesotho, Namibia, Repu- } \\
\text { blika Południowej Afryki, } \\
\text { Suazi }\end{array}$ & 1974 & $\begin{array}{l}\text { rand } \\
\text { południo- } \\
\text { woafry- } \\
\text { kański }\end{array}$ & $\begin{array}{l}\text { Bank Centralny Re- } \\
\text { publiki Południowej } \\
\text { Afryki (South African } \\
\text { Reserve Bank) }\end{array}$ \\
\hline $\begin{array}{l}\text { Strefa franka } \\
\text { pacyficznego }\end{array}$ & $\begin{array}{l}\text { Nowa Kaledonia, } \\
\text { Polinezja Francuska, } \\
\text { Wallis i Futuna }\end{array}$ & 1945 & $\begin{array}{l}\text { frank pa- } \\
\text { cyficzny }\end{array}$ & $\begin{array}{l}\text { Instytut Emisyjny } \\
\text { Terytoriów Zamorskich } \\
\text { (Institution d'Emission } \\
\text { d'Outre-Mer) }\end{array}$ \\
\hline
\end{tabular}

Źródło: opracowanie własne na podstawie: Salvatore (2010: 730-731); Ustalenia ... (2006: 40). 
Strefa franka CFA w Afryce obejmuje 14 państw afrykańskich skupionych w dwóch ugrupowaniach integracyjnych, mających charakter unii walutowych. Są to Zachodnioafrykańska Unia Gospodarcza i Walutowa (fr. UEMOA - Union Économique et Monétaire Ouest-Africaine), która obejmuje osiem państw afrykańskich: Benin, Burkina Faso, Gwinea-Bissau, Mali, Niger, Senegal, Togo i Wybrzeże Kości Słoniowej, oraz Wspólnota Ekonomiczna i Monetarna Afryki Centralnej (fr. CEMAC - Communauté Économique et Monétaire de l'Afrique Centrale) obejmująca sześć państw Afryki Środkowej: Czad, Demokratyczną Republikę Konga, Gabon, Gwineę Równikową, Kamerun oraz Republikę Środkowoafrykańską (por. Zabielski 1999: 159 i n.). Przyjmuje się, że istotny wpływ na zaawansowanie procesów integracji w Afryce miały przekonania o pozytywnym wpływie tych procesów na poziom inwestycji sektora prywatnego, wzrost PKB, przeciętny poziom życia $\mathrm{w}$ społeczeństwie, przekształcenia $\mathrm{w}$ regionie oraz wzrost efektywności poprzez otwarcie rynków (szerzej: Jaber 1979: 254). Integracja ta może być również postrzegana jako platforma promująca stabilność polityczną i społeczną państw członkowskich oraz stymulująca procesy wzrostu i rozwoju gospodarczego poprzez wzrost handlu regionalnego i współpracy międzyregionalnej (por. Zafar, Kubota 2003: 1-41).

Historycznie rzecz ujmując, integracja w krajach afrykańskich ma swoje źródła w czasach kolonialnych i może być postrzegana jako kontynuowanie wspólnej historii opartej na kolonialnej przeszłości. Wraz z rozwojem kolonializmu francuskiego ${ }^{1}$ państwo to ustanowiło na terenie swoich kolonii strefę franka kolonialnego, powiązaną ściśle z frankiem francuskim, jednocześnie ujednolicającą afrykański system monetarny (Ndiaye 2010: 130).

Pierwsze unie o charakterze gospodarczo-politycznym były tworzone przez Francuzów, którzy na kolonizowanych terenach utworzyli dwa związki: Francuską Afrykę Zachodnią (AOF - Afrique Occidentale Française) w 1898 r., składającą się z Senegalu, Gwinei, Wybrzeża Kości Słoniowej, Sudanu (później Mali), Dahomej (późniejszy Benin), Górnej Wolty (później Burkina Faso), Mauretanii i Nigru oraz Francuską Afrykę Równikową (AEF - Afrique Equatoriale Française), utworzoną w 1910 r., grupującą Czad, Ubangi-Szari (później Republikę Środkowoafrykańską), Kongo i Gabon. Francuska część Kamerunu pozostawała poza tymi ugrupowaniami i była nadzorowana bezpośrednio przez Francję. Pozostałe kraje tworzące obecnie UEMOA i CEMAC były kolonizowane przez Brytyjczyków, Portugalczyków lub Niemców (Kamerun).

Oficjalną datą ustanowienia franka CFA $^{2}$ jest 25 grudnia 1945 r. wraz z oficjalnym ratyfikowaniem przez Francję układów z Bretton Woods (Décret

${ }^{1}$ Poza Francją największym imperium kolonialnym w Afryce była Wielka Brytania, która ustanowiła na terenach swoich kolonii tzw. currency board, powiązany z funtem szterlingiem.

2 Skrót CFA pierwotnie oznaczał Colonies Françaises d'Afrique (Francuskie Kolonie Afrykańskie). W roku 1958, kiedy została ustanowiona V Republika Francuska, CFA stało się skrótem 
$\mathrm{n}^{\circ}$ 45-0136/1945) i przystąpieniem przez ten kraj do I Deklaracji Parytetowej Międzynarodowego Funduszu Walutowego (MFW). Powstały wówczas trzy różne jednostki monetarne, funkcjonujące na trzech wyodrębnionych rejonach ${ }^{3}$ :

- frank Francji Metropolitalnej, funkcjonujący również na terenach Północnej Afryki i Antylach Francuskich, oznaczany skrótem FF;

- frank Francuskich Kolonii Pacyfiku, oznaczany jako FCFP;

- frank Francuskich Kolonii Afryki, oznaczony FCFA.

Ustanawiając poszczególne systemy monetarne, ustalono jednocześnie stałe kursy wymiany: 1 frank CFP był równy 2,40 FF, a 1 frank CFA - 1,70 FF. Parytet franka CFA, od chwili ustanowienia, był czterokrotnie modyfikowany. Po raz pierwszy zmiana nastąpiła w roku 1948, wraz z dewaluacją franka metropolitalnego, druga miała miejsce w roku $1960 \mathrm{z}$ chwilą wprowadzenia nowego franka, a trzecia związana była z 50\% dewaluacją franka CFA. Ostatnia natomiast powiązana była $z$ wprowadzeniem wspólnej waluty euro w miejsce franka (tab. 2).

Tabela 2

Parytet franka CFA (FCFA) względem franka francuskiego (FF) i euro (EUR)

\begin{tabular}{|c|c|}
\hline Rok modyfikacji & Parytet \\
\hline 1945 (ustanowienie) & 1 FCFA $=1,70 \mathrm{FF}$ \\
\hline 1948 & 1 FCFA $=2,00 \mathrm{FF}$ \\
\hline 1960 & 1 FCFA $=0,02 \mathrm{FF}$ \\
\hline 1994 & $1 \mathrm{FCFA}=0,01 \mathrm{FF}$ \\
\hline 1999 & 1 FCFA $=0,001525 \mathrm{EUR}$ \\
\hline
\end{tabular}

Źródło: opracowanie własne na podstawie Banque des États... (2014).

Za stały kurs wymiany jest współodpowiedzialna, poza bankami centralnymi obu unii, również Francja, która gwarantuje wymienialność obu walut. W zamian za gwarancję wymienialności banki centralne obu ugrupowań są zobowiązane do przekazywania 50\% należności zagranicznych na tzw. rachunek operacyjny prowadzony oddzielnie dla każdego z nich przez Skarb Francuski. Pozostała suma służy regulowaniu zobowiązań państw strefy, przy czym francuski Skarb Państwa jest zobowiązany do dostarczania bankom centralnym funduszy w przypadku gdy środki pozostające do dyspozycji są niewystarczające do pokrycia bieżących zobowiązań. Zgodnie z przyjętymi ustaleniami w przypadku gdy należności za-

od Communauté française d'Afrique (Francuska Wspólnota Afryki). Od czasu uzyskiwania niepodległości przez poszczególne kraje Afryki (lata 60. XX w.) CFA oznacza Communauté Financière Africaine (Afrykańska Wspólnota Finansowa).

${ }^{3}$ Ze względu na charakter pracy w dalszej części będą analizowane jedynie afrykańskie strefy franka. 
graniczne zostają uznane za niewystarczające na pokrycie zaistniałego deficytu, Francja może jednostronnie postanowić o dewaluacji franka CFA (por. Allechi, Niamkey 1994: 1148; Ndiaye 2010: 135-137).

Strefa franka CFA jest podzielona na dwa podregiony monetarne, które są administrowane i nadzorowane przez niezależne instytucje banku centralnego, oddzielne dla każdego regionu. Każda strefa emituje „,własnego” franka, którym nie można się posługiwać w drugiej strefie. Ewentualna wymiana franka „zachodniego" na „wschodni” lub „wschodniego” na „zachodni” może się odbywać jedynie poprzez oficjalny sektor finansowo-bankowy. Przepływy kapitałowe w obrębie każdej podstrefy oraz pomiędzy podstrefami a Francją są jednak de facto swobodne, a jedyne restrykcje mają na celu walkę z nielegalnymi transferami kapitałów.

Pierwsza podstrefa, Zachodnioafrykańska Unia Gospodarcza i Walutowa została ustanowiona 10 stycznia 1994 r. traktatem w Dakarze, na mocy którego siedem krajów Afryki Zachodniej: Benin, Burkina Faso, Wybrzeże Kości Słoniowej, Mali, Niger, Senegal i Togo ustanowiło wspólną unię monetarną i przyjęło wspólną walutę, franka CFA. 2 maja 1997 r. do strefy dołączyła Gwinea-Bissau. Podstawowe cele funkcjonowania tego ugrupowania zostały określone w artykule 4 Traktatu Dakarskiego (1997) i należą do nich:

- wzmocnienie konkurencyjności gospodarczej i finansowej państw członkowskich w ramach otwartego, konkurencyjnego i prawnie zharmonizowanego rynku;

- zapewnienie spójności różnych polityk gospodarczych państw członkowskich za pomocą procedury wielostronnego nadzoru;

- ustanowienie wspólnego rynku z zapewnieniem swobodnego przepływu osób, towarów, usług i kapitału oraz swobodnej przedsiębiorczości, a także wprowadzonej wspólnej taryfy zewnętrznej i wspólnej polityki handlowej;

- koordynacja krajowych polityk sektorowych poprzez realizację wspólnych działań i porozumień w zakresie prawa pracy, ochrony środowiska, planowania, transportu i telekomunikacji, rolnictwa, energetyki, przemysłu i górnictwa;

- harmonizacja ustawodawstwa państw członkowskich, zwłaszcza systemu podatkowego, w celu wspierania wspólnego rynku i wzmocnienia konkurencyjności gospodarczej i finansowej państw członkowskich.

W celu osiągnięcia zakładanych celów państwa członkowskie przeniosły część uprawnień krajowych na rzecz instytucji ponadnarodowych. Działania Unii są finansowane $\mathrm{z}$ dochodów uzyskiwanych ze wspólnej taryfy celnej oraz procentu dochodów podatkowych każdego państwa członkowskiego. UEMOA może również zaciągać kredyty oraz pozyskiwać dotacje i pomoc zewnętrzną w celu realizacji działań statutowych, m.in. pomoc od organizacji międzynarodowych, w tym Unii Europejskiej i UNCTAD, współfinansujących jej działalność i politykę (West African... 2007: 2-5).

Unia ta jest nadzorowana przez Bank Centralny Państw Afryki Zachodniej (fr. BCEAO - Banque Centrale des États de l'Afrique de l'Ouest). Instytucja ta została założona w roku 1959 jako następca powołanego w 1955 roku L'Institut 
d'Emission de l'Afrique Occidentale Française et du Togo (Instytut Emisyjny Francuskiej Afryki Zachodniej i Togo). Do podstawowych zadań BCEAO zalicza (por. Banque Centrale des États... 2014):

- emisję franka dla krajów wspólnoty;

- realizację przyjętych założeń polityki monetarnej;

- zapewnienie stabilności funkcjonowania systemu finansowego krajów UEMOA;

- nadzór nad stabilnością i sprawnym funkcjonowaniem systemów rozliczeniowych;

- wspieranie reform ekonomicznych przyjętych przez Radę UEMOA;

- zarządzanie rezerwami walutowymi wszystkich krajów UEMOA.

Z kolei druga podstrefa, Wspólnota Gospodarcza i Walutowa Afryki Środkowej (CEMAC) obejmuje sześć krajów (Kamerun, Republika Środkowoafrykańska, Czad, Kongo, Gwinea Równikowa i Gabon) w Afryce Środkowej. W ramach integracji monetarnej kraje członkowskie CEMAC ustanowiły wspólne instytucje nadzorujące system finansowy, prowadzone krajowe polityki makroekonomiczne oraz harmonizację systemu prawnego. Utworzenie Wspólnoty Ekonomicznej i Monetarnej miało doprowadzić do (por. Zafar, Kubota 2003: 1-41):

- poprawy konkurencyjności gospodarczej;

- osiągnięcia konwergencji gospodarczej poprzez koordynację polityk gospodarczych, przede wszystkim w zakresie krajowych polityk budżetowych i wspólnej polityki pieniężnej;

- utworzenia wspólnego rynku opartego na swobodnym przepływie osób, towarów, usług i kapitału;

- koordynacji polityk sektorowych.

Wspólnota ta jest obsługiwana przez Bank Krajów Afryki Centralnej (BEAC - Banque des États de l'Afrique Centrale), założony w 1972 r. i odpowiadający za (Czernichowski 2010: 171):

- emisję franka dla krajów unii;

- politykę monetarną państw UEMOA;

- zarządzanie rezerwami walutowymi państw członkowskich;

- politykę kursową;

- współodpowiedzialny za stabilność makroekonomiczną i finansową w strefie.

Ze względu na przyjęcie stałego kursu wobec euro sytuacja afrykańskich unii monetarnych jest specyficzna, bowiem wyklucza w pełni autonomiczną politykę pieniężną i kursową, a ewentualne działania muszą uwzględniać zachowanie sztywnego kursu względem euro.

$\mathrm{Z}$ uwagi na współpracę oraz postępujące procesy integracji gospodarczej pomiędzy oboma ugrupowaniami zdecydowano się na ustanowienie faktycznej unii celnej - Organizacji dla Harmonizacji Prawa Afrykańskiego (fr. OHADA - Organisation pour l'harmonisation en Afrique du droit des daffaires), która poprzez harmonizowanie prawa lokalnego ma prowadzić do rozwoju integracji 
ekonomicznej. Celem jest integracja ekonomiczna, prawna i polityczna subregio$\mathrm{nu}$, prowadząca do utworzenia nowego ugrupowania integracyjnego na bazie istniejących (por. Study on the Establishment ... 2010: 154; Michailof 2007: 94-98).

\section{EFEKTY INTEGRACJI DLA KRAJÓW STREFY FRANKA CFA (LATA 1990-2012)}

Zgodnie z teorią największe korzyści związane z funkcjonowaniem w jednolitym obszarze walutowym są związane z utrzymywaniem stabilnego poziomu cen wynikającego z prowadzenia niezależnej polityki pieniężnej oraz stałego kursu walutowego. Ponadto uwypukla się ewentualny pozytywny wpływ na inne zmienne makroekonomiczne, takie jak wzrost gospodarczy czy poziom bezrobocia.

Oba ugrupowania charakteryzują się, w porównaniu do innych ugrupowań integracyjnych, relatywnie niską populacją (tab. 3). Należy jednak zaznaczyć, że względny wzrost liczby ludności w okresie 1990-2013 był najwyższy ze wszystkich ugrupowań - zarówno w Zachodnioafrykańskiej Unii Gospodarczej i Walutowej, jak i Wspólnocie Ekonomicznej i Monetarnej Afryki Centralnej wzrosty oscylowały w granicach $90 \%$, co należy powiązać z wysokim wskaźnikiem urodzeń w Afryce, pomocą humanitarną (w tym medyczną) dla krajów afrykańskich oraz zmianami w systemie opieki zdrowotnej w tych krajach.

Wskaźnik wzrostu cen w badanym okresie (tab. 4a i 4b) generalnie zmniejszał się, przy czym ulegał on istotnym wahaniom ${ }^{4} \mathrm{w}$ poszczególnych krajach w kolejnych latach. Niemniej jednak pod kątem osiągania stabilności cen należy ocenić oba ugrupowania pozytywnie.

Zarówno CEMAC, jak i UEMOA w analizowanym okresie wykazywały relatywnie wysokie tempo wzrostu gospodarczego (tab. 5). W okresie 1990-2013 jedynie państwa ASEAN rozwijały się dynamiczniej, osiągając wyższe średnie tempo wzrostu gospodarczego. Należy jednak zaznaczyć, że takie tempo wzrostu mogło wynikać raczej ze zwiększonego światowego popytu na surowce, w które państwa Afryki są bogate, niż ze zmian strukturalnych i ogólnej poprawy konkurencyjności tych krajów.

Z kolei wartości handlu wewnętrznego oraz ich udział w handlu ogółem w obu ugrupowaniach był istotnie zróżnicowany (tab. 6). W przypadku Zachodnioafrykańskiej Unii Gospodarczej i Walutowej wartości względne dla importu oscylowały w granicach $10 \%$, a dla eksportu w granicach 14\%. Te same zmienne we Wspólnocie Ekonomicznej i Monetarnej Afryki Centralnej były znacząco niższe: wartość udziału importu wewnątrzwspólnotowego wyniosła średnio 2,5\%, natomiast

${ }^{4}$ Ze względu na wysokie różnice między poszczególnymi krajami w poszczególnych latach oraz brak części danych celowo nie podano wartości średniej dla całego ugrupowania w danym roku. 
wartość dla eksportu oscylowała wokół 1,1\%. Uznać należy, że w obu ugrupowaniach nie wystąpiły lub wystąpiły w wąskim zakresie zjawiska kreacji i przesunięcia handlu - dla porównania, w krajach UE wartości handlu wewnętrznego wynoszą średnio 64\% ogółu handlu tych krajów (UNCTAD Statistics ... 2014).

Poziom bezrobocia w poszczególnych krajach w kolejnych latach przyjmował relatywnie niski poziom, przy czym stopa bezrobocia różniła się istotnie w poszczególnych krajach (tab. 7a i 7b). Należy stwierdzić, że sam proces integracji nie oddziaływał zasadniczo na poziom bezrobocia w krajach integrujących się - przez cały badany okres stopa bezrobocia zmieniała się nieznacznie, właściwie pozostając bez zmian.

\section{PODSUMOWANIE}

Podejmując próby osiągnięcia stabilności ekonomicznej, społecznej i politycznej oraz wprowadzenia swoich państw na ścieżki stałego i wysokiego wzrostu gospodarczego wiele krajów afrykańskich zdecydowało się na wprowadzenie reform strukturalnych oraz pogłębienie procesów integracji ekonomicznej.

Jednym z najciekawszych przypadków integracji monetarnej w Afryce jest strefa franka CFA, funkcjonująca jako walutowa w dwóch ugrupowaniach integracyjnych: Zachodnioafrykańskiej Unii Gospodarczej i Walutowej oraz Wspólnocie Ekonomicznej i Monetarnej Afryki Centralnej. Wzajemna współpraca ma relatywnie długą historię, wynikającą przede wszystkim ze wspólnej historii. Korzyści związane z funkcjonowaniem tej strefy są przede wszystkim związane z zapewnieniem stabilności cen, która faktycznie wystąpiła w obu ugrupowaniach. Inne korzyści związane z funkcjonowaniem wewnątrz ugrupowania integracyjnego, takie jak zwiększenie tempa wzrostu gospodarczego, pozytywny wpływ na wzrost handlu zagranicznego czy rynek pracy z uczestnictwem, właściwie nie wystąpiły. 
Tabela 3

Liczba ludności wybranych ugrupowań integracyjnych w latach 1990-2013 (dane w tys. osób)

\begin{tabular}{|c|c|c|c|c|c|c|}
\hline Rok & UEMOA & CEMAC & UE & NAFTA & ASEAN & MERCOSUR \\
\hline 1990 & 53965,18 & 24638,59 & 464550,4 & 371862,7 & 443735,3 & 216167,7 \\
\hline 1991 & 55575,26 & 25358,46 & 466086,2 & 376631,7 & 452231,6 & 219896,6 \\
\hline 1992 & 57260,35 & 26096,82 & 482319,5 & 381450,6 & 460590,5 & 223559,3 \\
\hline 1993 & 59004,65 & 26854,18 & 483795,9 & 386348,5 & 468829,4 & 227185,3 \\
\hline 1994 & 60784,94 & 27631,21 & 485096,0 & 391366,5 & 476979,4 & 230815,6 \\
\hline 1995 & 62584,59 & 28428,56 & 486150,7 & 396523,9 & 485063,3 & 234477,7 \\
\hline 1996 & 64400,97 & 29246,23 & 486907,6 & 401846,5 & 493082,1 & 238179,6 \\
\hline 1997 & 66240,32 & 30084,54 & 487426,8 & 407296,2 & 501026,2 & 241906,8 \\
\hline 1998 & 68105,80 & 30944,79 & 487885,9 & 412751,0 & 508896,2 & 245637,0 \\
\hline 1999 & 70003,32 & 31828,61 & 488531,4 & 418046,9 & 516691,1 & 249337,5 \\
\hline 2000 & 71938,78 & 32737,09 & 489536,5 & 423070,9 & 524410,3 & 252981,9 \\
\hline 2001 & 73913,46 & 33670,93 & 490962,6 & 427767,2 & 532062,4 & 256568,5 \\
\hline 2002 & 75930,66 & 34629,69 & 492743,8 & 432180,7 & 539649,2 & 260097,2 \\
\hline 2003 & 78001,40 & 35611,94 & 494770,4 & 436424,3 & 546220,9 & 263545,1 \\
\hline 2004 & 80139,42 & 36615,56 & 496873,2 & 440664,1 & 553588,1 & 266885,2 \\
\hline 2005 & 82355,90 & 37639,02 & 498922,3 & 445019,6 & 560844,4 & 270100,2 \\
\hline 2006 & 84655,02 & 38681,94 & 500891,8 & 449527,8 & 567975,1 & 273176,5 \\
\hline 2007 & 87038,66 & 39744,80 & 502803,5 & 454148,3 & 574995,3 & 276124,4 \\
\hline 2008 & 89512,38 & 40828,10 & 504627,1 & 458830,4 & 581962,0 & 278981,0 \\
\hline 2009 & 92081,53 & 41932,67 & 506337,0 & 463492,6 & 588952,3 & 281798,8 \\
\hline 2010 & 94749,58 & 43059,15 & 507913,5 & 468075,8 & 596017,8 & 284616,0 \\
\hline 2011 & 97520,53 & 44207,92 & 509334,4 & 472568,1 & 603181,0 & 287445,5 \\
\hline 2012 & 100393,70 & 45378,93 & 510588,6 & 476991,4 & 610414,9 & 290276,6 \\
\hline
\end{tabular}

Źródło: opracowanie własne na podstawie UNCTAD Statistics... (2014). 
章

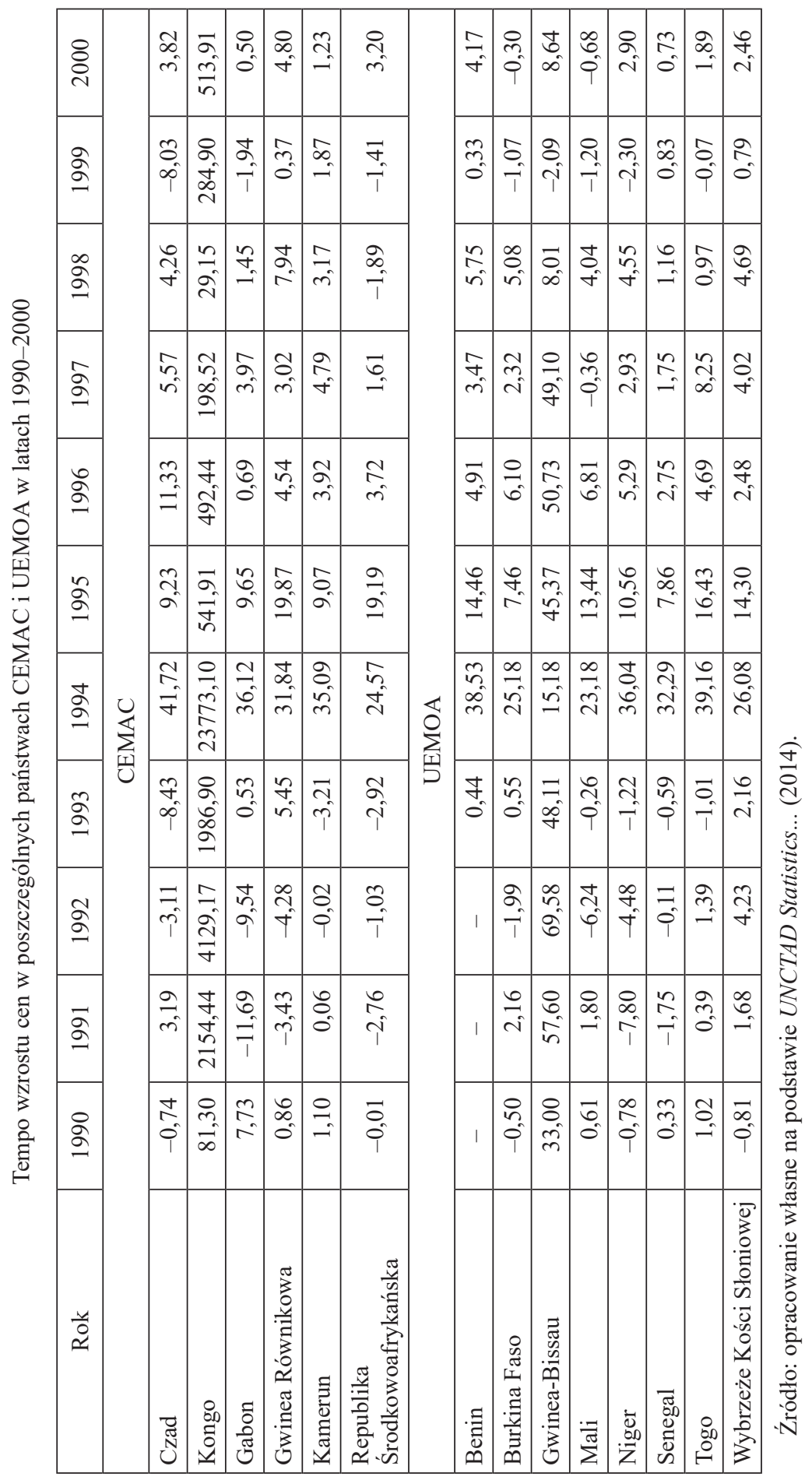




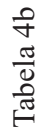

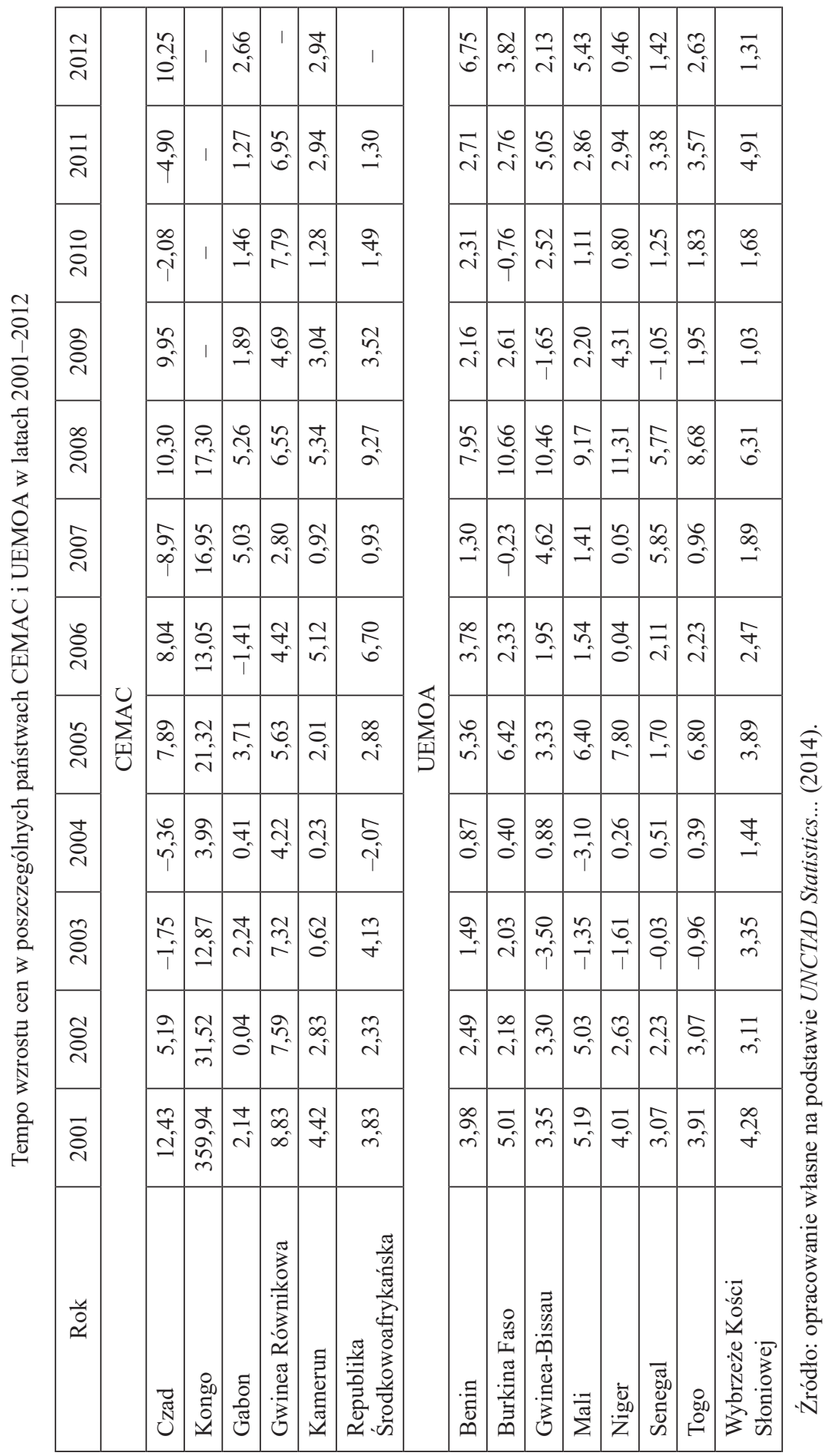


Tabela 5

Tempo wzrostu gospodarczego wybranych ugrupowań integracyjnych w latach 1990-2013

\begin{tabular}{|c|c|c|c|c|c|c|}
\hline Rok & UEMOA & CEMAC & UE & NAFTA & ASEAN & MERCOSUR \\
\hline 1990 & 0,80 & $-0,72$ & 2,43 & 1,96 & 8,29 & $-2,54$ \\
\hline 1991 & 1,06 & $-0,81$ & 1,29 & 0,04 & 7,00 & 3,43 \\
\hline 1992 & 1,03 & $-3,97$ & 2,02 & 3,35 & 6,99 & 2,09 \\
\hline 1993 & $-0,04$ & $-10,14$ & $-0,07$ & 2,69 & 7,67 & 4,38 \\
\hline 1994 & 2,67 & $-1,05$ & 2,98 & 4,12 & 7,86 & 4,76 \\
\hline 1995 & 6,39 & 6,78 & 2,81 & 2,19 & 7,90 & 3,01 \\
\hline 1996 & 6,21 & 8,05 & 2,00 & 3,76 & 7,40 & 2,41 \\
\hline 1997 & 4,82 & 4,69 & 2,94 & 4,62 & 4,07 & 4,49 \\
\hline 1998 & 5,20 & 2,66 & 2,97 & 4,45 & $-7,19$ & 0,78 \\
\hline 1999 & 3,74 & 0,31 & 2,96 & 4,72 & 3,77 & $-1,14$ \\
\hline 2000 & $-0,50$ & 2,11 & 3,93 & 4,25 & 6,11 & 3,26 \\
\hline 2001 & 3,65 & 5,39 & 2,04 & 0,92 & 2,63 & 0,62 \\
\hline 2002 & 1,02 & 7,95 & 1,29 & 1,76 & 5,06 & $-0,76$ \\
\hline 2003 & 3,08 & 4,32 & 1,48 & 2,64 & 5,59 & 1,19 \\
\hline 2004 & 2,63 & 9,59 & 2,61 & 3,74 & 6,53 & 7,41 \\
\hline 2005 & 4,25 & 10,61 & 2,18 & 3,29 & 5,90 & 4,86 \\
\hline 2006 & 3,00 & 8,82 & 3,37 & 2,77 & 6,01 & 5,32 \\
\hline 2007 & 3,27 & 12,87 & 3,20 & 1,87 & 6,65 & 6,79 \\
\hline 2008 & 4,11 & 9,25 & 0,35 & $-0,09$ & 4,15 & 5,47 \\
\hline 2009 & 3,04 & 3,05 & $-4,54$ & $-2,90$ & 1,55 & $-0,46$ \\
\hline 2010 & 4,46 & 4,62 & 2,05 & 2,71 & 7,96 & 6,74 \\
\hline 2011 & 0,55 & 4,23 & 1,65 & 2,02 & 4,60 & 3,97 \\
\hline 2012 & 5,74 & 6,39 & $-0,40$ & 2,75 & 5,44 & 1,63 \\
\hline $\begin{array}{l}\text { średnie tempo } \\
\text { wzrostu gospo- } \\
\text { darczego w la- } \\
\text { tach 1990-2013 }\end{array}$ & 3,16 & 4,23 & 1,73 & 2,48 & 5,28 & 2,92 \\
\hline
\end{tabular}

Źródło: opracowanie własne na podstawie UNCTAD Statistics... (2014). 
Wartość i udział handlu wewnętrznego dla UEMOA i CEMAC w latach 1995-2012

\begin{tabular}{|c|r|r|r|r|r|r|r|r|}
\hline \multirow{2}{*}{ Rok } & \multicolumn{4}{|c|}{ UEMOA } & \multicolumn{3}{c|}{ CEMAC } \\
\cline { 2 - 10 } & \multicolumn{2}{|c|}{ import } & \multicolumn{2}{|c|}{ eksport } & \multicolumn{2}{c|}{ import } & \multicolumn{2}{c|}{ eksport } \\
\cline { 2 - 10 } & wartość & udział & wartość & udział & wartość & udział & wartość & udział \\
\hline 1995 & 551,47 & 7,48 & 1054,53 & 16,10 & 158,36 & 2,53 & 134,92 & 1,20 \\
\hline 1996 & 672,85 & 9,25 & 940,27 & 13,07 & 231,60 & 2,87 & 184,35 & 1,36 \\
\hline 1997 & 654,99 & 9,18 & 908,61 & 12,93 & 257,87 & 3,17 & 211,38 & 1,50 \\
\hline 1998 & 834,37 & 10,32 & 950,60 & 12,82 & 202,94 & 2,53 & 183,62 & 1,66 \\
\hline 1999 & 833,36 & 10,77 & 1023,80 & 14,07 & 165,98 & 2,03 & 128,71 & 1,02 \\
\hline 2000 & 730,95 & 10,42 & 975,71 & 15,24 & 192,87 & 2,43 & 156,54 & 0,91 \\
\hline 2001 & 795,11 & 10,58 & 887,92 & 13,34 & 228,88 & 2,40 & 187,14 & 1,17 \\
\hline 2002 & 861,21 & 10,63 & 993,52 & 11,90 & 305,99 & 2,73 & 200,77 & 1,08 \\
\hline 2003 & 1241,39 & 12,21 & 1363,36 & 14,57 & 321,09 & 2,38 & 268,11 & 1,20 \\
\hline 2004 & 1498,84 & 11,71 & 1690,63 & 15,09 & 362,16 & 2,36 & 272,62 & 0,85 \\
\hline 2005 & 1496,89 & 9,85 & 1716,90 & 14,22 & 415,10 & 2,12 & 349,77 & 0,70 \\
\hline 2006 & 1700,70 & 10,63 & 1894,56 & 13,87 & 571,87 & 2,48 & 409,25 & 0,66 \\
\hline 2007 & 1827,99 & 9,19 & 2113,11 & 14,95 & 1022,76 & 3,16 & 962,81 & 1,23 \\
\hline 2008 & 2555,56 & 10,09 & 2647,46 & 14,93 & 1002,09 & 2,25 & 971,34 & 0,87 \\
\hline 2009 & 2169,90 & 9,87 & 2295,40 & 12,65 & 1198,11 & 2,62 & 1037,80 & 1,45 \\
\hline 2010 & 2380,11 & 9,82 & 2533,88 & 12,21 & 1517,20 & 3,48 & 1393,76 & 1,52 \\
\hline 2011 & 2457,88 & 9,71 & 2645,21 & 11,13 & 1161,73 & 2,15 & 1061,82 & 0,90 \\
\hline 2012 & 2918,42 & 9,96 & 3124,06 & 13,51 & 1207,28 & 1,99 & 990,01 & 0,79 \\
\hline średni udział & & & & & & & & \\
\hline w latach & - & 10,09 & - & 13,70 & - & 2,54 & - & 1,12 \\
\hline $995-2012$ & & & & & & & & \\
\hline
\end{tabular}

Źródło: opracowanie własne na podstawie UNCTAD Statistics... (2014). 
$\frac{\pi}{\frac{\pi}{0}}$

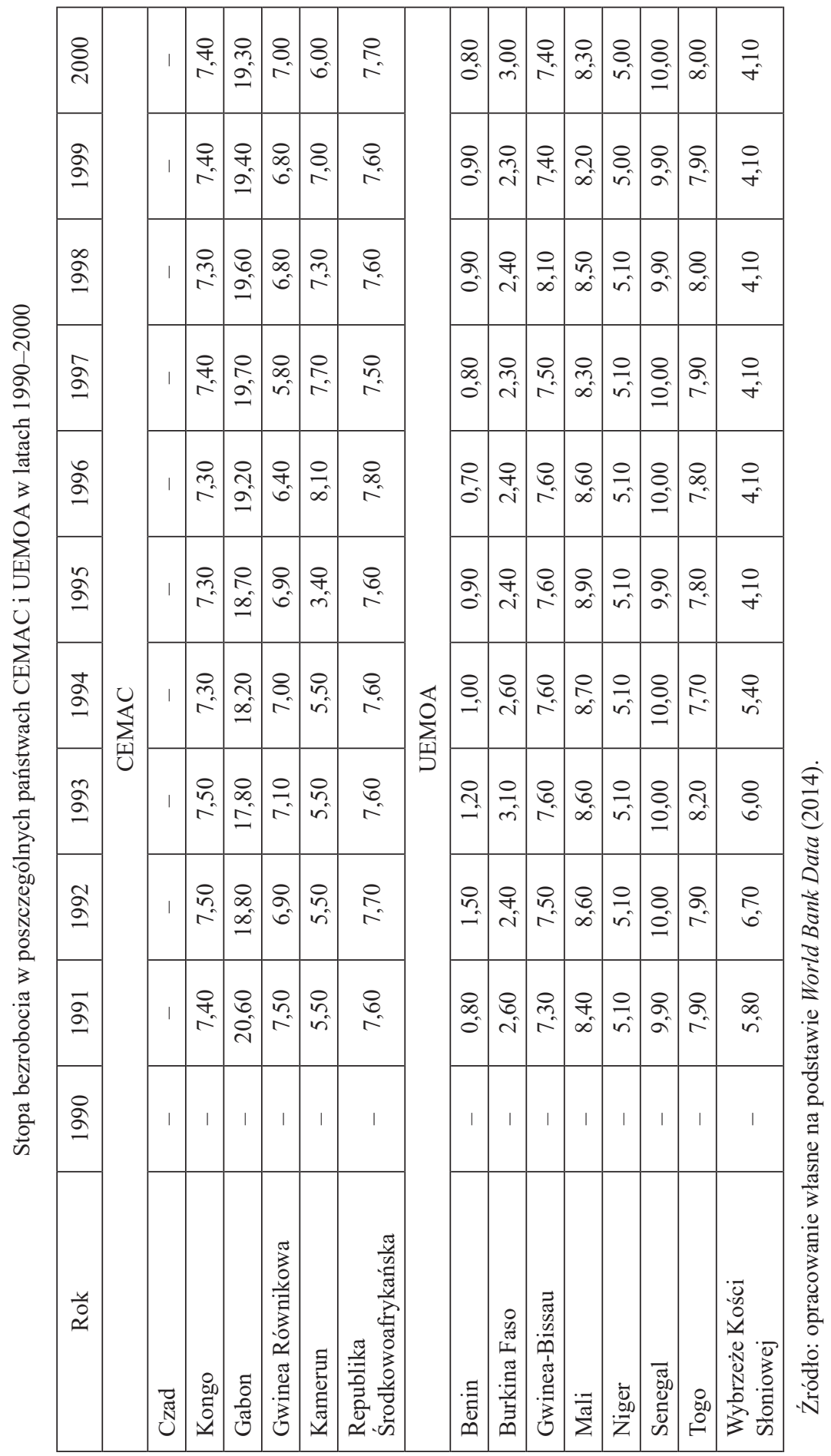


$\frac{\pi}{0}$
$\frac{\pi}{0}$
$\frac{\pi}{10}$

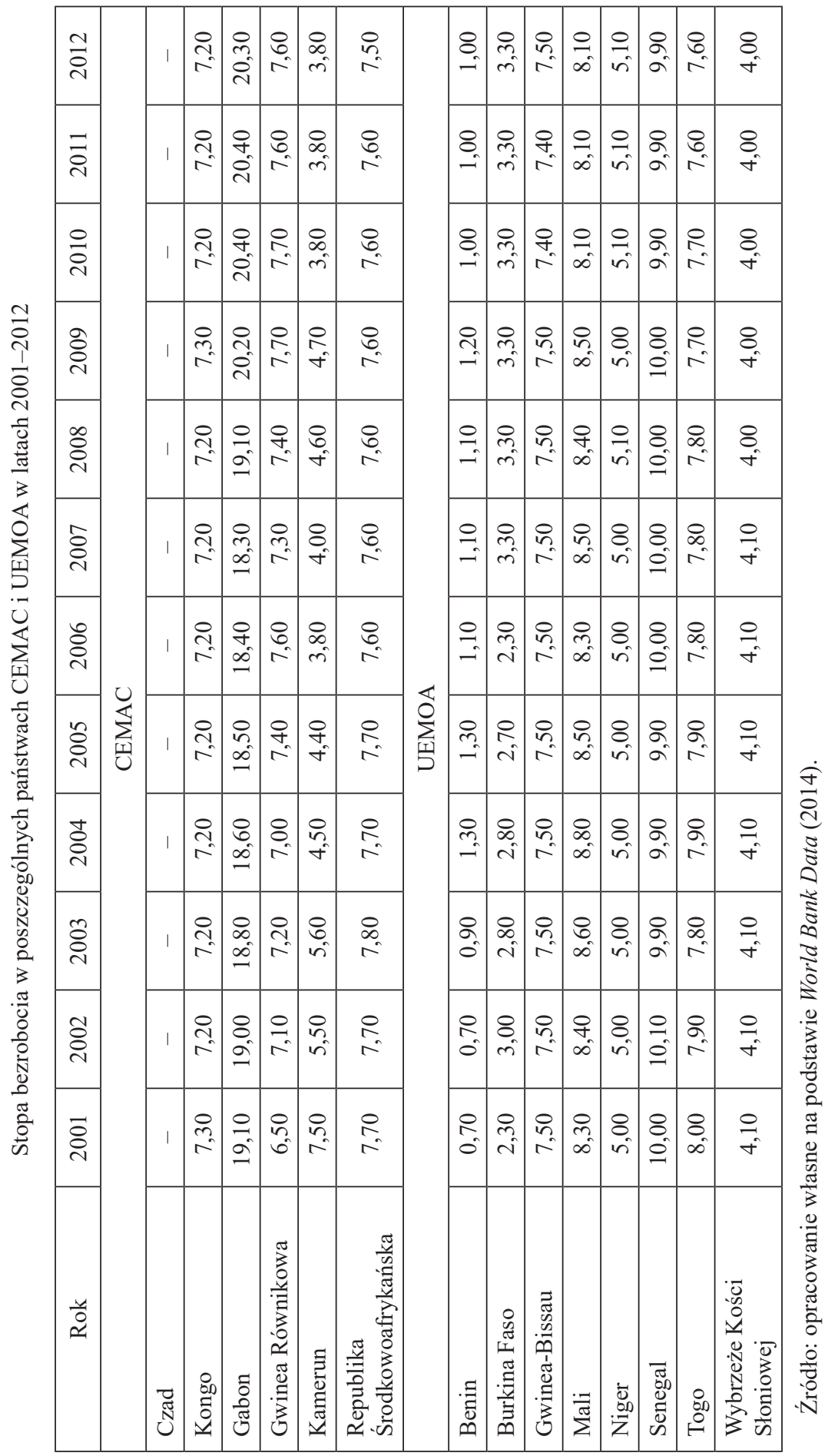




\section{BIBLIOGRAFIA}

Allechi M., Niamkey M. A. (1994), Evaluating the net gains from the CFA Franc Zone membership: A different perspective, „World Development”, Vol. 22, Issue 8, s. 1148.

Balassa B. (1961), The Theory of Economic Integration, George Allen \& Urwin LTD, London.

Banque Centrale des États de l'Afrique de l'Ouest, Présentation, Missions, Dates-clés, http://www. bceao.int/Presentation.html (dostęp: 4.11.2014).

Banque des États de l'Afrique Centrale, Histoire du Franc CFA (2014), https://www.beac.int/index. $\mathrm{php} /$ billets-et-pieces/histoire-du-franc-cfa (dostęp: 4.11.2014).

Begg D., Fischer S., Dornbusch R. (2003), Makroekonomia, PWE, Warszawa.

Bilski J. (2006), Międzynarodowy system walutowy. Kierunki ewolucji, PWE, Warszawa.

Bożyk P., Misala J. (2003), Integracja ekonomiczna, PWE, Warszawa.

Budnikowski A. (2006), Międzynarodowe stosunki gospodarcze, PWE, Warszawa.

Coffey P., Presley J. R. (1976), European Monetary Integration, Macmillan Press, London.

Czernichowski K. (2010), Integracja afrykańska - uwarunkowania, formy wspótpracy, instytucje, CeDeWu, Warszawa.

Décret n 45-0136 du 25 décembre 1945, Fixant la valeur de certaines monnaies des territoires d'outre-mer libellées en francs, https://www.legifrance.gouv.fr/affichTexte.do?cidTexte=JORFTEXT000000682456\&categorieLien=id (dostęp: 8.06.2016).

Frankel J., Rose A. (1998), The endogenity of the optimum currency area criteria, „Economic Journal", No. 108 (449), s. 1009-1025.

Gandolfo G. (1992), Monetary unions, [w:] J. Eatwell, M. Milgate, P. Newman (red.), New Palgrave Dictionary of Money and Finance, II, Macmillan, London.

Jaber T. (1979), The relevance of traditional integration theories to LDC's, „Journal of Common Market Studies", Vol. 9, No. 3, s. 254.

Kamecki Z. J. (1967), Pojęcie i typy integracji gospodarczej, „Ekonomista”, nr 1, s. 93-94.

Kenen P. B. (1969), The optimum currency area: an eclectic view, [w:] R. Mundell, A. Swoboda (red.), Monetary Problems of the International Economy, Chicago University Press, Chicago.

Krugman P. (1993), Lesson from Massachusetts for EMU, [w:] F. Torres, F. Gavazzi (red.), Adjustment and Growth in the European Monetary Union, Cambridge University Press, Cambridge.

Machlup F. (1986), Integracja gospodarcza - narodziny i rozwój idei, PWN, Warszawa.

Makać A. (2001), Międzynarodowa integracja gospodarcza - podstawowe problemy teoretyczne, [w:] E. Oziewicz (red.), Procesy integracyjne we wspótczesnej gospodarce światowej, PWN, Warszawa.

McKinnon R. I. (1963), Optimum currency areas, „American Economic Review”, No. 53, s. 717-725.

Michailof S. (2007), Il faut rompre avec la parité fixe du Franc CFA, „Jeune Afrique”, No. 9411, s. $94-98$.

Molle W. (1992), The Economics of European Integration (Theory, Practice, Policy), Dartmouth Publishing Company, Aldershot.

Mundell R. A. (1961), A Theory of Optimum Currency Areas, „The American Economic Review”, Vol. 51, No. 4, s. 657-665.

Mundell R. A. (1968), International Economics, The Macmillan Company, New York.

Ndiaye B. (2010), Przestrzeń i granice monetarne we wspótczesnej Afryce na przykładzie strefy franka CFA, Forum Politologiczne, t. 10, INP UWM, Olsztyn, s. 130-137.

Rising International Economic Integration. Opportunities and Challenges (2005), „European Economy", No. 6, European Commission, Brussels.

Salvatore D. (2010), International Economics, Wiley, Hoboken, New Jersey.

Stehn J. (1992), Ausländische Direktinvestitionen in Industrieländern, „Kieler Studien”, No. 245, Institut für Weltwirtschaft, Tübingen, s. 108-112. 
Study on the Establishment of a Monetary Union among the Partner States of the East African Community (2010), European Central Bank, http://www.eac.int/rmo/index.php?option=com docman\&task=doc_download\&gid=139\&Itemid=238 (dostęp: 8.06.2016).

Tchorek G. (2010), Teoretyczne podstawy integracji walutowej, [w:] P. Kowalewski, G. Tchorek, J. Górski, Mechanizmy funkcjonowania strefy euro, NBP, Warszawa.

The LIME assessment framework: a methodological tool to compare, in context of the Lisbon Strategy, the performance of EU Member States in terms of GDP and in terms of twenty policy areas affecting growth (2008), „European Economy”, Occasional Papers 41, European Commission, Brussels.

Traité de UEMOA (1994), article 4, http://www.uemoa.int/Documents/TraitReviseUEMOA.pdf (dostęp: 6.06.2016).

UNCTAD Statistics: International trade (2014), http://unctad.org/en/pages/Statistics.aspx (dostęp: 4.11.2014).

Ustalenia w sprawie reżimu pieniężnego i kursowego między strefa euro a wybranymi krajami i terytoriami trzecimi (2006), „Biuletyn Miesięczny Europejskiego Banku Centralnego”, nr 4, s. 40.

Verde A. (2009), In and out of monetary unions: lessons from, and risk for the EMU. An alternative approach to monetary unions, [w:] L. S. Talani (red.), The Future of EMU, Palgrave Macmillan, London.

West African Economic and Monetary Union, Benin and Senegal. Overview (2007), United Nations, http://unctad.org/en/Docs/ditcclp20071overview en.pdf (dostęp: 8.06.2016).

Wojtyna A. (1998), Teoretyczne kontrowersje wokół Unii Gospodarczej i Walutowej, „Gospodarka Narodowa", nr 9, numer specjalny, s. 8-15.

World Bank Data (2014), http://data.worldbank.org/indicator/BX.KLT.DINV.CD.WD (dostęp: 4.11.2014).

Wyplosz Ch. (2006), European Monetary Union, the Dark Side of a Major Success, „Economic Policy", Vol. 21, No. 46, s. 207-261;

Zabielski K. (1999), Finanse międzynarodowe, PWN, Warszawa.

Zafar A., Kubota K. (2003), Regional Integration in Central Africa: Key Issues, „Africa Region Working Paper Series", No. 52, s. 1-41.

\title{
Michat Zaremba
}

\section{MONETARY INTEGRATION IN WEST AFRICA - DEVELOPMENT AND FUNCTIONING OF CFA FRANK AREA}

\begin{abstract}
This article aims to present the development and history of the African CFA franc zone, which is the official currency in two groupings of African integration - the West African Economic and Monetary Union and Economic and Monetary Community of Central Africa. In the first part of the paper focuses on the theoretical aspects of monetary integration, while the second has been devoted to the analysis of monetary integration processes on the continent.
\end{abstract}

Keywords: economic integration, Africa, currency union. 